\title{
МЕНТАЛЬНА КАРТА ЯК ЗАСІБ ВІЗУАЛІЗАЦІЇ НАВЧАЛЬНОЇ ІНФОРМАЦЇ̈ УЧНЯМИ ЗАКЛАДІВ ЗАГАЛЬНОЇ СЕРЕДНЬОЇ ОСВІТИ НА УРОКАХ УКРАЇНСЬКОЇ МОВИ ТА ЛІТЕРАТУРИ
}

У статті окреслено ефективність використання ментальних карт як одного зі шляхів покращення якості знань і розвитку критичного мислення учнів закладів загальної середньої освіти у процесі вивчення украӥнської мови та літератури. Здійснено аналіз основних функиіональних характеристик та способів застосування ментальних карт, схарактеризовано ӥхню структуру та особливості створення.

Ключові слова: інформаційно-комунікаційні технологіï, ментальна карта, карта знань, інтерактивні методи, навчально-пізнавальна діяльність, комунікативна компетентність.

Mental maps help to improve students' memory, develop the ability to identify and express their own opinions, develop skills of educational and cognitive activities, structure communication skills, subconsciously, without difficulty assimilates and consolidates material, increases interest in learning Ukrainian language and literature, and establishes successful interaction of teacher and students in class.

The modern development of civilization is characterized by the accelerated progress of technologies that cause natural changes in human life and affect all spheres of activity, including education, which at the same time becomes the basis and prerequisite for the development of a society united by common values and culture. The world community has entered a new era when the labor market no longer needs workers who can only reproduce the previous experience of mankind. Currently, there is a growing demand for professionals with original thinking, capable of non-standard solutions, those who know how to navigate in the information space, work in a dynamic environment. The school today feels the need for a teacher who is constantly striving for creative search, has the skills of research, experimental activities; high level of information culture. The ability to renew, openness to the new (innovation) is a characteristic feature of the new pedagogy.

Pedagogical innovation is of paramount value for pedagogical practice, especially for creative teachers who teach new Ukrainian children in the New Ukrainian School. Due to intensive reform, in accordance with the requirements of the time, modern school, in the process of forming a fundamentally new system of general education, given the shortcomings of the traditional education system: inability and unwillingness of children to learn, unformed values of self-development and education a modern school must develop the abilities necessary for its students to self-determine, the ability to make informed decisions and the ability to realize themselves in society. If we consider a person's life as his individual project, then to solve these problems requires the ability to create, experience - personal and considered by example, his behavioral reactions, knowledge and skills or his life competencies.

Key words: information and communication technologies, mental map, knowledge map, interactive methods, educational and cognitive activity, communicative competence.

Саме від того, як ви збираєте, організуєте та використовуєте інформацію, залежить, переможете ви чи програєте...

Білл Гейтс

Постановка проблеми. Для сучасного етапу розвитку суспільства характерний надшвидкий прогрес у галузі інноваційних технологій, що проникають в усі без винятку сфери людської діяльності, зокрема й освітню.

В останні роки у зв'язку з модернізацією освіти, збільшенням обсягу навчального матеріалу запам' ятовувати нові знання стає все важче. Людський мозок не настільки довго зберігає інформацію, яка була записана, прочитана або почута. Якщо отримані знання були занотовані у звичайному вигляді, мозку доводиться просто заносити цю інформацію у пам'ять. Але йому набагато простіше буде оперувати з великим блоком інформації, якщо ці дані пов'язати певним асоціативним рядом. Учені та лікарі неодноразово доводили, що людина краще запам'ятовує інформацію, якщо вона представлена не тільки у структурованому вигляді, але й зображена графічно [8, с. 87].

Як же успішно впоратися зі значним потоком інформації, що надходить? Як витрачати на обробку та аналіз цієї інформації якнайменше часу і сил? Ідеальним рішенням $€$ сучасний метод «згортання» значних блоків інформації до найголовніших понять, названий методом ментальних карт, що вважається 
альтернативою текстовим конспектам. Ментальні карти якнайкраще підходять для використання в школах, їх можна застосовувати в будь-яких видах завдань, залучаючи учнів різного віку до активного творчого мислення, організації й вирішення проблем.

Аналіз наукових досліджень і публікацій. Проблемі використання ментальних карт в освітньому процесі присвячено переважно праці закордонних учених, серед яких - Т. Б’юзен, Б. Санто, Б. Твісс, Р. Фостер, В. Хартман, Й. Шумпетер та ін. Серед вітчизняних дослідників варто виокремити розвідки О. Аксьонова, Л. Гончаренко, О. Литвиненко, Р. Медведєва, А. Найдьоновї, Н. Оксентюк, М. Черній, І. Шахіної та інших учених. Використанню ментальних карт у вивченні окремих предметів присвячено напрацювання А. Гордєєвої, В. Машкіної, С. Процької.

Так, британський психолог Т. Б'юзен у своїх працях називає ментальні карти («mind map) «хорошою формою для нотаток», «багатогранним пристроєм, що тренує кожен м'яз розуму» [1]. Досвід використання ментальних карт у викладанні гуманітарних дисциплін пропонує й українська дослідниця Н. Оксентюк, акцентуючи увагу на результативності впровадження даного методу, про що свідчить активізація умінь школярів застосовувати емоції у процесі усвідомлення як через образні асоціації, набуття умінь дослідницької діяльності, так і через збудження процесів синтезування, узагальнення, порівняння, вільного виходу на комунікацію [5]. Окремої уваги заслуговує також посібник для вчителів та учнів «Iнтелект-карти як інструмент ефективної роботи з інформацією» А. Найдьонової [3], де наведено детальні рекомендації щодо створення ментальних карт.

Метод ментальних карт досить поширений і в шкільній практиці. Досвід і приклади його реалізації у викладанні різних предметів представлені на численних українських педагогічних сайтах, як-от «Всеосвіта», «Освіторія», «На Урок», сайтах окремих учителів, а також закладів освіти.

Мета статті - розкрити важливість використання ментальних карт як візуального способу вивчення інформації на уроках української мови і літератури, визначити їнню ефективність в освітньому процесі сучасного закладу загальної середньої освіти.

Реалізація мети передбачає розв' язання таких завдань:

- окреслити переваги використання ментальних карт;

- з'ясувати доречність їх застосування на різних етапах уроків української мови та літератури.

Виклад основного матеріалу. Ментальні карти, або по-іншому інтелект-карти, карти розуму, карти пам'яті, карти знань, - унікальна технологія роботи 3 інформацією, що допомагає не тільки організувати й упорядкувати інформацію, а й краще сприйняти, зрозуміти та запам'ятати іiі; сукупність діаграм і схем, різноманітних кольорових ліній, геометричних фігур, а також чітко підібраних ключових слів при вивченні теми, розділу, котрі в наочному вигляді демонструють думки, тези, пов'язані між собою та об'єднані загальною ідеєю [4].

Уперше ментальну карту як метод візуалізації інформації застосував філософ Порфирій Тирський ще в III столітті нашої ери, аби краще зрозуміти концепції Аристотеля [6]. Щодо появи теорії інтелект-карт, то вона з'явилася аж на початку 70-х років $\mathrm{XX}$ ст. завдяки відомому британському психологові
Тоні Б’юзену. Ретельно вивчивши досвід мислення кращих «умів» людства (Леонардо да Вінчі, Альберта Ейнштейна, Томаса Едісона, Джеймса Джойса та ін.), Б'юзен дійшов висновку, що ці генії максимально використовували всі ментальні можливості свого мозку, на відміну від пересічної людини, яка використовує лише п'ять його відсотків. Він вирішив «змусити свій мозок працювати». Поєднавши цей досвід із досягненнями сучасної психології в галузі пам'яті та мислення, вчений розробив технологію мислення та запам'ятовування інформації, яку згодом назвав «інтелект-карти» («mind maps»). Найцікавіше, що в основу складання інтелект-карт було покладено метод асоціацій [3].

Використання ментальних карт на уроках української мови та літератури - один зі способів того, як найкраще вирішити проблеми із прогалинами у фактичних знаннях учнів, допомогти їм в осмисленні інформації, запам'ятовуванні, схематичному зображенні, поетапному записі та класифікації думок. Саме тому інтелект-карти доцільно використовувати як додаткові інструменти у процесі навчання, вирішення проблемних ситуацій, ухвалення рішень, написання статей тощо.

Карта знань дає змогу систематизувати й структурувати матеріал, стежити за певним розвитком подій, персонажів, встановлювати змістові й смислові зв'язки. Щодо вмінь та навичок освітньої діяльності, необхідних на уроках української мови і літератури, то ментальні карти є «засобом спрощення, схематичного зображення» різних видів мисленнєвих операцій, які покращують пам'ять, концентрацію уваги, чуття міри, розвивають критичне мислення.

Ментальні карти неабияк привертають увагу учнів, налаштовуючи їх на спільну працю; роблять заняття і презентації цікавішими й змістовнішими; матеріал уроку завдяки їм стає менш громіздким, його можна легко пристосовувати до умов, що змінюються. Такі карти не тільки оперують фактичним матеріалом, а й демонструють послідовність, конструктивність, творчість, оскільки акцентують увагу на інформації, що безпосередньо стосується предмета, який вивчається. Наприклад, інтелектуальні карти ідеально підходять для використання на комбінованих уроках української мови, зокрема на етапі актуалізації опорних знань, умінь та навичок учнів, та можуть застосовуватися до будь-яких видів завдань.

Варто зауважити, що побудова ментальних карт повинна здійснюватися виключно учнями, а викладач при цьому має бути консультантом, помічником, порадником i аж ніяк не виконавцем, інакше така карта знань не матиме практичного значення, адже учень, який не розумітиме зв'язків між іiі структурними частинами, не зможе нею скористатися. Тому кінцевий вигляд карти може відрізнятися від первинного задуму педагога. Крім того, ментальна карта не має на меті відповісти на всі питання та все детально розповісти, вона передусім слугує схемою, йдучи за якою учень зможе розв'язати поставлені завдання [6].

На нашу думку, ментальна карта - це своєрідна асоціативна мережа, що складається з образів і слів, адже саме слово є головною одиницею мови. Учень самостійно пригадує або знаходить слово, що активізує процеси пам'яті та мислення. Представляючи кожне поняття у вигляді картинки, він використовує складний ланцюг навичок, характерних як для лівої, 
так і правої півкуль мозку. Використання малюнків образів полегшує розуміння і запам'ятовування, адже будь-яка картинка, що постає в уяві, набагато легше запам'ятовується і швидше відтворюється в пам'яті, ніж текст (саме 3 цією метою і використовуються різні кольори і малюнки).

Таким чином, у створенні інтелект-карт задіяні уява, творче та критичне мислення, усі види пам'яті (зорова, слухова, механічна), що сприяє результативному запам'ятовуванню.

Залежно від ступеня згортання інформації, можна виокремити три види інтелект-карт:

- детальні - максимальна репрезентація інформації, навчального матеріалу;

- схематичні - спрощено-узагальнене представлення інформації (ключової ідеї);

- символічні-максимальне згортання інформації 3 використанням знаків, малюнків, зображень [9].

Для того, щоб учень зміг самостійно створити ментальну карту, йому варто скористатися, наприклад, таким алгоритмом:

1. Прочитай уважно текст (правило).

2. Віднайди ключові слова, поняття, терміни; запиши їх у центрі аркуша.

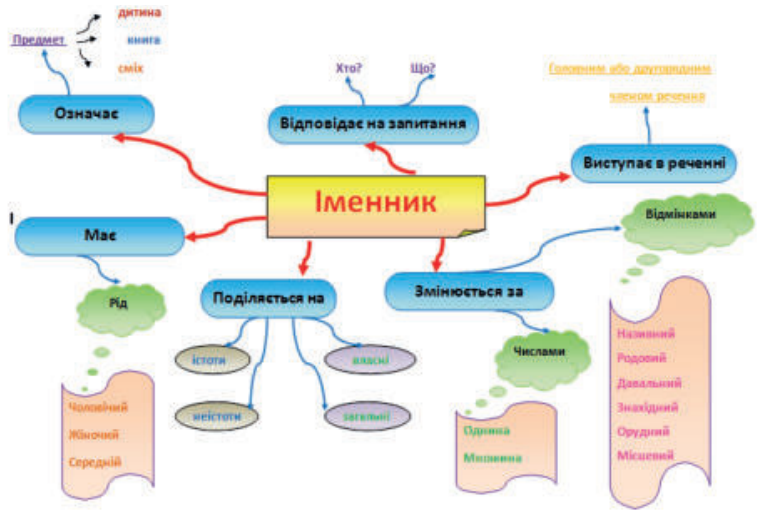

3. Запиши поряд слова, які можна відтворити в уяві або закодувати за допомогою малюнків.

4. Відредагуй готову ментальну карту.

5. Закріпи нові знання за допомогою презентації візуалізованої роботи з текстом.

Щодо уроків української мови та літератури, то на них слід використовувати інтелект-карти для: візуалізації змісту теми уроку; складання словесного портрету опису художнього твору / автора; створення різноманітних проєктів та оригінальних презентацій. Таку карту можна використовувати на різних етапах уроку: під час актуалізації опорних знань; у процесі мотивації пізнавальної діяльності (для розкриття теми уроку); в ході узагальнення й систематизації (як домашне завдання) тощо.

Як приклад, розгляньмо ментальні карти, що використовуються на уроці української мови в ході вивчення самостійних частин мови (у нашому випадкуіменника та прикметника) (див. рис. 1). Означені інтелект-карти мають очевидні переваги перед класичними презентаціями, оскільки дають змогу не лише оцінити матеріал цілісно, всебічно, а й при цьому не замінюють схем і таблиць, навпаки, виступають своєрідним доповненням до них.

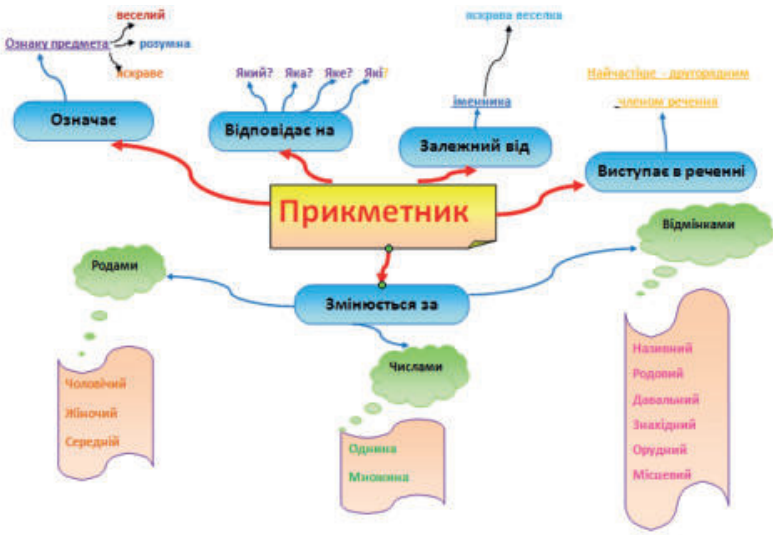

Рис. 1. Ментальні карти, розроблені під час вивчення самостійних частин мови (за матеріалами [2])

Ментальні карти на уроках української літератури найдоцільніше застосовувати на етапі закріплення пройденого матеріалу. Вони допомагають фіксувати значний обсяг інформації, структурувати та аналізувати твір, запам'ятовувати основні факти, поняття та вислови, формулювати думку, співставляти події, давати характеристику героїв, резюмувати книги, вірші, п’єси, аналізувати матеріали із засобів масової інформації, підсумовувати прочитане (див. рис. 2.).

Тобто, йдеться не про звичайне запам'ятовування чи запис, а про осмислене сприйняття, швидше й глибше розуміння, що дозволяє відтворювати знання навіть через тривалий проміжок часу. До речі, для формування в здобувачів освіти понятійно-термінологічної бази до карти включено терміни разом із їх тлумаченням.

Неабияк доречні ментальні карти: при вивченні поезії, адже практика показує, що віршовані тексти учні не лише гірше сприймають, а й важче запам'ятовують; у процесі написання творів-роздумів, творів-описів, творів-розповідей, есе, власних висловлювань, виконання творчих завдань. Вони допоможуть логічно сформулювати думку, не втратити важливі ідеї, вибудувати сюжетну лінію та розставити акценти у творі. При цьому варто пам'ятати, що основне завдання ментальної карти - не відповісти детально на всі питання, а передусім слугувати схемою, спираючись на яку, учень без особливих зусиль зможе вирішити поставлені завдання [6].

Серед позитивних сторін інтелект-карт варто виокремити такі: 1) у процесі їх створення відбувається чотирикратне повторення навчального матеріалу (читання 3 розумінням; виокремлення головного; наповнення карти шляхом надиктовування (безпосереднє написання тексту), що є запорукою високого рівня запам'ятовування; 2) вони допомагають організувати успішну та плідну взаємодію між учнями, перетворити іiі на творчий процес.

Таким чином, використання ментальних карт в освітньому процесі - сучасний і дієвий спосіб викладання навчального матеріалу, який зробить будь-який урок, зокрема й української мови та літератури, цікавим і пізнавальним, дозволить учителеві якнайкраще донести до учнів матеріал, а школярам відповідно допоможе краще його засвоїти. Створити ментальну карту не складає особливих зусиль, зокрема в мережі Інтернет $є$ безліч відеороликів та відеоуроків із детальними інструктажами. Залишається тільки обрати найбільш зручне програмне забезпечення: Сасоо https://cacoo.com/; Візуальний словник - http://vslovar. org.ru/; Mindmeister - http://www.mindmeister.com/; Mapmyself - http://www.mapmyself.com; Bubbl - http:// bubbl.us/; Mindomo - http://www.mindomo.com/ та ін. [7]. 


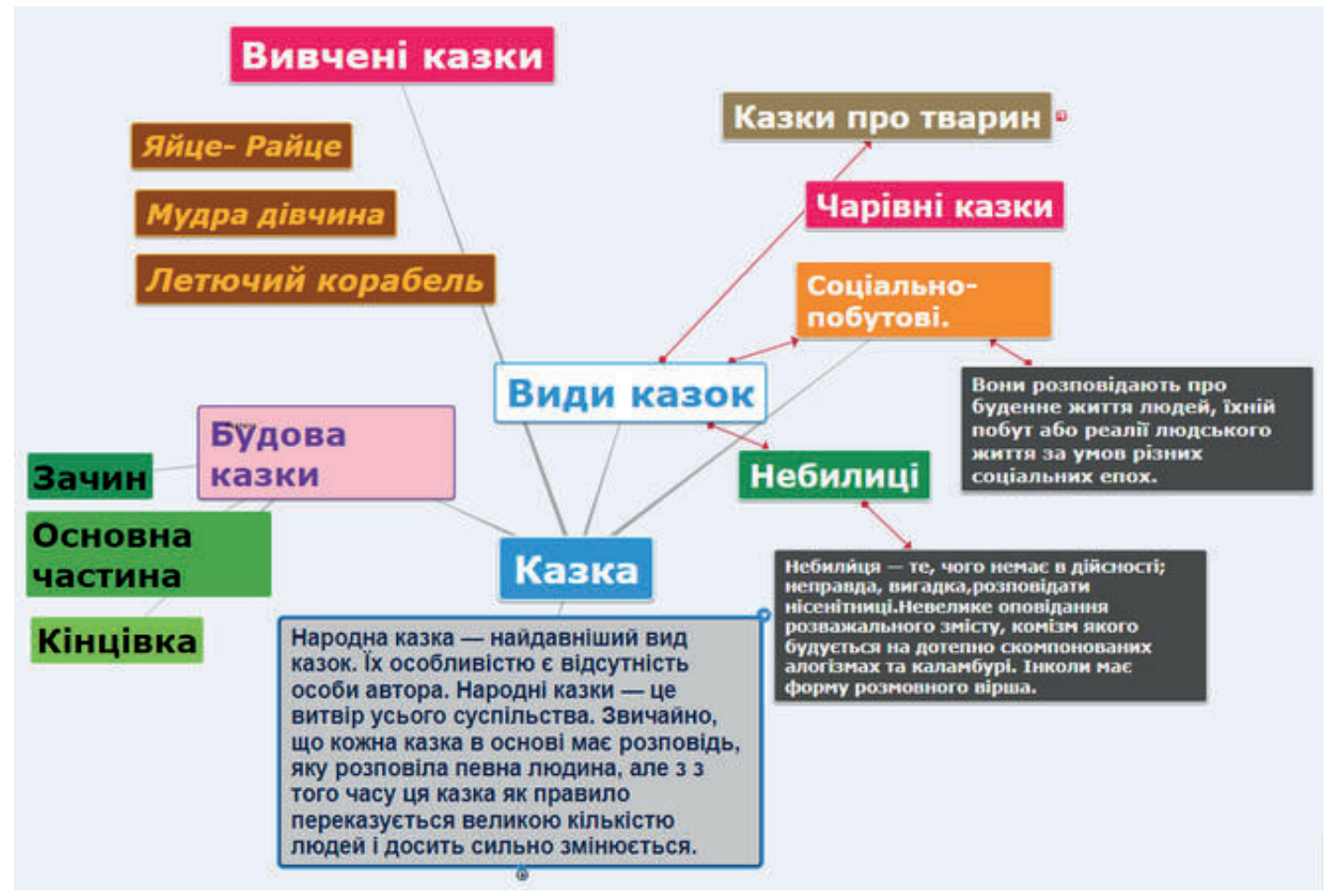

Рис. 2. Ментальна карта «Види казок» (за матеріалами [2])

Висновки. Зважаючи на викладене вище, зазначимо, що використання ментальних карт забезпечує високий ступінь залученості учнів до освітнього процесу, адже при їх використанні вони із пасивних отримувачів знань перетворюються на активних учасників освітнього процесу. Застосовуючи інтелект-карти у навчанні, діти вчаться вибирати, структурувати запам'ятовувати та відтворювати ключову інформацію.

На уроках української мови вони допомагають одночасно утримувати у свідомості значну кількість інформації, встановлюючи смислові зв'язки між ії частинами, що дозволяє швидко відтворити знання, а також систематизувати і структурувати навчальний матеріал, що сприяє його розумінню, а отже, застосуванню на практиці. На уроках української літератури інтелект-карти доцільно використовувати при вивченні поезії, написанні власного висловлення чи есе тощо. Зрештою такі карти сприяють успішній взаємодії викладача та учнів, розвитку їхніх творчих здібностей, допомагають розвивати креативне і критичне мислення, пам'ять і увагу, роблять процес навчання цікавішим і результативнішим.

Подальші наші дослідження в даному напрямі плануємо спрямувати на подальше дослідження використання ментальних карт на уроках української мови та літератури у $33 \mathrm{CO}$.

\section{СПИСОК ВИКОРИСТАНОЇ ЛТЕРАТУРИ}

1. Б’юзен Т. Научите себя думать. Минск : Попурри, 2004. 192 с.

2. Всеосвіта: спільнота активних освітян. Офіиійний вебпортал. URL: https://vseosvita.ua/ (дата звернення: 10.09.2020).

3. Найдьонова А. Інтелект-карти як інструмент ефективної роботи з інформацією : посібник для вчителів та учнів. URL: https://en.calameo.com/read/004373 434dec4e2bf2b83 (дата звернення: 05.10.2020).

4. Овчарук О. В. Цифрова педагогіка в підготовці вчителя XXI століття. Цифрова компетентність су- часного вчителя нової украӥнської школи : зб. тез доповідей учасників Всеукр. наук.-практ. семінару (м. Київ, 28 лют. 2018 р.) / за заг. ред. О. Е. Коневщинської, О. В. Овчарук. Київ : Інститут інформаційних технологій і засобів навчання НАПН України, 2018. С. 50-53.

5. Оксентюк Н. В. Можливості застосування ментальних карт у навчальному процесі. Технологї навчання : науково-методичний збірник. Рівне : НУВГП, 2015. Вип. 15. С. 194-208.

6. Погребенник I. Ментальні карти при викладанні української мови і літератури у закладах професійно-технічної освіти. Українська професійна освіта. 2018. № 4. C. 71-77. URL: file:///C:/Users/\%D0\%90 $\%$ D0\%B $\% \%$ D0\%BC\%D0\%B8\%D0\%BD $\%$ D0\%B $\%$ D $1 \% 81 \% \mathrm{D} 1 \% 82 \% \mathrm{D} 1 \% 80 \% \mathrm{D} 0 \% \mathrm{~B} 0 \% \mathrm{D} 1 \% 82 \% \mathrm{D} 0 \% \mathrm{BE}$ $\% \mathrm{D} 1 \% 80 /$ Downloads/\%D0\%A3\%D0\%BA\%D1\%80$\% \mathrm{D} 0 \% \mathrm{BF} \% \mathrm{D} 1 \% 80 \% \mathrm{D} 0 \% \mathrm{BE} \% \mathrm{D} 1 \% 84-\% \mathrm{D} 0 \% \mathrm{BE} \% \mathrm{D}$ $1 \% 81 \% \mathrm{D} 0 \% \mathrm{~B} 2 \% \mathrm{D} 1 \% 96 \% \mathrm{D} 1 \% 82 \% \mathrm{D} 0 \% \mathrm{~B} 0 \_4(2018)$ (1)-71-77.pdf (дата звернення: 12.10.2020).

7. Хачатрян С. Карти знань, їх призначення, редактор карт знань. URL: http://www.kievoit.ippo.kubg. edu.ua/ (дата звернення: 12.10.2020).

8. Черній М. Карти знань як засіб збільшення ефективності засвоєння навчального матеріалу учнями та їх застосування за допомогою веб-сервісів. Проблеми підготовки сучасного вчителя. 2012. № 6. Ч. 1. С. 87-94.

9. Шахіна I., Медведєв Р. Використання ментальних карт у навчальному процесі. Наукові записки [Кіровоградського державного педагогічного університету імені Володимира Винниченка]. Серія «Проблеми методики фізико-математичної і технологічної освіти». 2015. Вип. 8 (3). С. 73-78. URL: http:// nbuv.gov.ua/UJRN/nz_pmfm_2015_8(3)__15 (дата звернення: 14.10 .2020$)$.

Дата надходження до редакиіï: 05.11.2020 p. 